\title{
Globalisation and ethnic jokes: A new look on an old tradition in Belarus and Estonia
}

\author{
Liisi Laineste \\ Estonian Literary Museum \\ liisi@folklore.ee
}

\author{
Anastasiya Fiadotava \\ Tartu University \\ zhvaleuskaya@gmail.com
}

\begin{abstract}
Christie Davies, the renowned humour researcher and a passionate propagator of the comparative method in studying jokes, stressed the necessity of establishing a relationship between two sets of social facts: the jokes themselves on the one hand, and the social structure or cultural traditions wherein they disseminate on the other (Davies 2002: 6). He also inspired others to examine the differences and similarities in the patterns of jokes between different nations, social circumstances and eras. By doing this and building falsifiable models and generalisations of joking relationships, he changed the way we look at and analyse ethnic jokes.

This study returns to earlier findings of Estonian (Laineste 2005, 2009) and Belarusian (Astapova 2015; Zhvaleuskaya 2013, 2015) ethnic jokes and takes a look at new trends in fresh data. Starting with the jokes from the end of the 19th century and ending with the most recent jokes, memes and other humorous items shared over the Internet, the paper will give an overview of how social reality interacts with the rules of target choice, above all describing the effect of globalisation on jokelore.
\end{abstract}

Keywords: ethnic humour, Belarus, Estonia, jokes as social facts, Internet, memes.

\section{Introduction}

Ethnic jokes are intricately connected to the social reality (Davies 1990, 1998, 2002, 2011, 2016 and elsewhere). Hence, it is reasonable to suggest that they change together with circumstances that give rise to them: with the particular social, political and cultural context. In recent decades, national and ethnic differences in humour production and evaluation are shifting as cultural borders become more ephemeral, partly due to the global reach of the media. The Internet has made jokes shorter, more visual, and less dependent on language- 
English has become the dominant language for humour circulation. This does not mean, however, that national and ethnic differences become erased. On the contrary, in some cases it signals a turn to stressing the local history of and a particular taste for humour. Even if the choice of pertinent joke targets may have grown due to increased cultural contacts, whether deliberate (access to the Internet and international mass media, frequent travelling) or less so (refugee crisis in 2015), different groups display individual preferences and insert subtle local cultural references into the humour they produce, share and enjoy.

Ethnic humour, side by side with jokes about sex and politics, has definitely been among the favourite topics at all times (see Shifman 2007: 198). When ethnic humour reflects the local traditions of target choice and relies thus more on the surrounding cultural patterns and other aspects of social reality, other joke categories, for example jokes about sex or animals, tend to display more universal and global qualities. We could assume that together with massive globalisation, ethnic aspects disappear from jokes and are replaced with more universal topics (jokes about online behaviour could be one of these, see Laineste \& Voolaid 2016). Ethnicity could stop being a laughing stock also with the global rise of political correctness, while the audience (who could potentially take offence) on the other hand widens.

However, ethnic jokes have been noted to flourish at the times when ethnicity is doubted or threatened (Kuipers 2006: 142), and in the light of the recent refugee crises in Europe or the racist statements of Donald Trump in America or other political leaders elsewhere in the world, ethnic identity is definitely a contested topic. Ethnic targets are still popular in humour, although they are not always identified by name but instead visualised through recognisable symbols (Boxman-Shabtai \& Shifman 2015) - through customs concerning food, clothes, or physiological features. Looking in a diachronic way at the development of the category of ethnic jokes in two Eastern European countries that share some important moments in history is a way to reveal what societal factors influence the popularity and inner dynamics of this controversial folk genre.

In this study, we present a diachronic survey of the target choice of the ethnic joke in Estonia and Belarus. We will start from the earliest joke collections available to us to pinpoint the first documented joke targets in the two countries. We then move on to discuss the effects of the Soviet and early post-Soviet period on the jokelore of the two regions. Finally, the new layers of ethnic humour available through the Internet and folklore collections are studied. The analysis will throw light on the tensions between the local and the global within a tradition, showing the changes in the direction of mockery from local numbskulls to foreign targets (e.g., immigrant/neighbouring/local groups versus ethnic groups or nations from the rest of the world) - and in some cases back to locals again in the search for a "local joking identity" (Laineste 2009: 124).

While describing jokes and their targets, we will refer to the theory of ethnic / targeted humour outlined by Christie Davies in his article "Ethnic Jokes, Moral Values and Social Boundaries", published in 1982. In the following monographs $(1990,1998,2002)$ and numerous articles on ethnic humour $(1987,1991,1999,2003)$ he elaborates on and expands the empirical range of the theory. To summarise his ideas, the theory proposes a set of universal rules for (ethnic) target choice in stupidity jokes. These posit that the stupid characters are chosen from among a group that is culturally close to the joke-teller and they often share a similar language. In addition to that, they are regarded as economically backward and as a rule make their living by doing low-status manual work. The joking relationship between joke-tellers and targets is characterised by asymmetry (for example, French about the Belgians, people from the Unites States about the Polish, Canadians about the Newfoundlanders etc, but not vice versa; for more examples see Davies 1990: 11). As 
Davies elaborated in 2011, there is an additional tension of the physical and the mental realms underpinning most of jokes done at the expense of the others.

A few recent studies on ethnic humour have touched upon the dilemmas of target choice in a constantly_virtually_ expanding world. Kuipers and van der Ent (2016) have found that among present-day ethnic jokes, there are numerous universal jokes that can be applied to various target groups over time. While the universal jokes are not relying on specific or real features of the group members, the picture they conjure of these groups is lopsided and doesn't always coincide with the social reality; instead it points at certain relationship between the joke-teller and the target group. The data collected by Kuipers and van der Ent (ibid) shows that the Dutch emerge as the positive characters who are presented in comparison to all the other targeted groups as clean, developed, etc.- quite in accordance with earlier studies that show the joke-tellers tend to favour one's own group. Joking at the expense of other groups reinforces their own identity (Fine \& Soucey 2005). In a slightly earlier study of Israeli humorous forwarded emails, Boxman-Shabtai \& Shifman (2015) have studied the changes involved in the process of ethnic humour going digital. They conclude that non-local joke targets (e.g., the Chinese in Israel) are more often shown visually through entrenched stereotypes, while locals are targeted through more traditional humour forms, e.g., jokes, and the used stereotypes are more detailed. In addition to this, the humour exposes a meta-level that ridicules not only the actual target but also anyone who actually holds such stereotypes of the target. Competing interpretations and metatexts thus interfere with the text and produce ambiguous, intertextual fields of meaning. Furthermore, they found that in contemporary ethnic humour, ethnicity is neutralised and often becomes a non-issue in these texts/images.

For this study, the following questions were asked:

- How popular have ethnic jokes been in Estonia and Belarus through these times?

- What are the main developments with regard to the targets of ethnic jokes from the late 19th century to the present day? Are there similarities and differences in the Fenno-Ugric (Estonian) and Slavic (Belarusian) cultural areas that geographically have both been in the zone of influence of Russia during the period we are analysing?

- Which ethnic groups are targeted now? What is the proportion of the locals (Estonians, Belarusians) as targets and which group is stigmatised the most?

- How does the visual plug into contemporary ethnic humour?

\section{Jokes and targets in Estonia and Belarus}

\subsection{Estonian data}

In the Estonian case, the data comes from three separate databases of jokes: the first one consists of approximately 1500 joke tales and was collected towards the end of the 19th century by Pastor Matthias Johann Eisen, who was particularly interested in folk tales and riddles. The second dataset covers the years 1950-2007, consisting of circa 50,000 jokes from Soviet and post-Soviet times, collected from printed and oral sources as well as from the internet. The third and most recent material (circa 500 jokes, humorous images and videos) was collected from oral folklore (school lore collection) as well as from internet humour sources. For the latter, meeldib.ee humour website ethnic humour category (consisting of mostly jokes) and the most popular humour/meme sharing groups on social media (mostly images and videos) were used. When the internet material was collected by browsing presentday "humour hubs" (Shifman 2007: 188), the school lore campaign of 2007 is a (regular, once in a decade) cross-Estonian enterprise where children from all school levels were 
handed out questionnaires concerning school lore; they filled it in during a day at school. The questionnaire included a section on humour and jokes, asking questions like "What were the last jokes you heard or told?", "Have you carried out or witnessed practical jokes and what were they like?", "What kind of humour is popular among your circle of friends?", etc.

\subsection{1. $1900 \mathrm{~s}$}

The first set of data covers the period 1880-1910, when Matthias Johann Eisen became interested in humour and started to put together a collection of joke tales. Collections of old folk jokes, edited by Eisen and collected by himself and his contributors were published in several volumes (1895-1910), each consisting of about 200 unique texts. In his foreword to Eesti Rahvanali ('Estonian Folk Joke', 1909), Eisen also claimed that joke tales (even if they have escaped the attention of collectors because they were too light-weight or frivolous) need to be documented and stored in archives for future generations. He stressed that a thin but omnipresent humour stream is an important aspect of Estonian folklore, visible for example through the trickster character Kaval-Ants (Sly Hans; ATU 1000-1199) in Estonian tales who often outplays his strong and mighty but stupid opponent, Vanapagan ('the Old Devil'), with a comic lightness and frequent use of humorous motifs. At the same time, these partly humorous stories carried a strong moralising and serious undertone. Eisen was biased in collecting jokelore, and referred to his preferences in the foreword of Eesti Rahvanali, stating that jokes must not be too obscene or profane/ungodly. Ethnic jokes escaped both of these restrictions and it may be because of this that ethnic jokes are the most numerous category in his collections (80 percent or the circa 1500 joke tales collected). Mentioning the ethnic identity of the main protagonist of the joke is a rule:

A Saare man [a man from the island of Saaremaa] bought a loaf of bread. He tied a string to the bread and pulled it along, saying, "Now you run after me, I am tired of running after you!"

(Eisen 1896/2002b No. 49: Leib nööri otsas. ['Bread on a string'.] H. Reisar, Halliste parish, Southwest Estonia.)

Jokes and joke tales target the peripheries-prevalently the islands off the western coast of Estonia (Saaremaa and Hiiumaa), but also the coastal people themselves, and less so the Setu people from southern Estonia who share a lot of traditions with the Russians. Some jokes target foreigners who happened to pass by their villages as travelling salesmen, soldiers or workforce, particularly Jews and Russians. In Eisen's "Eesti rahvanali" (1909), ethnic jokes target the following local ethnic groups, all with their distinct local dialects and ways of life: 


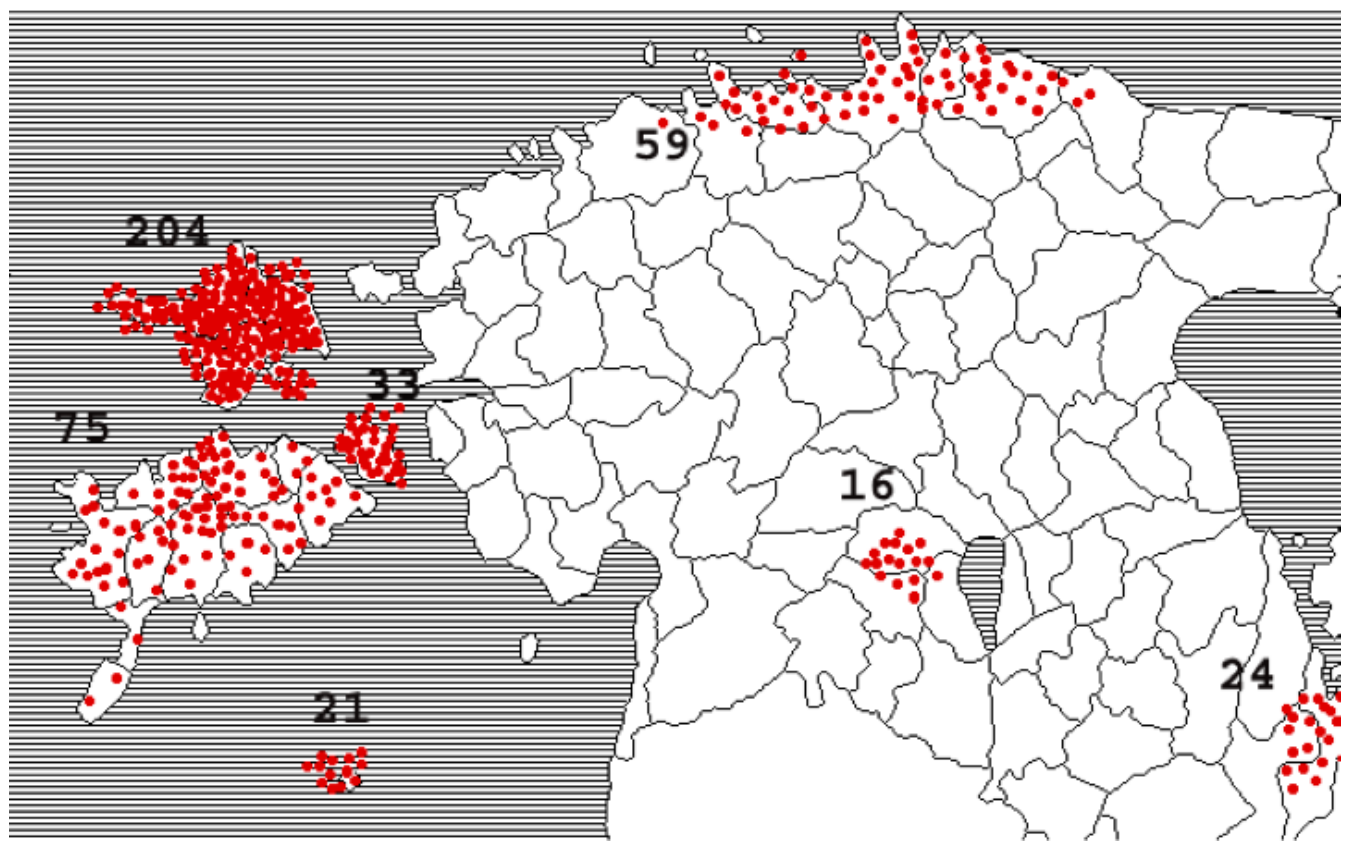

Figure 1. Targets of ethnic jokes in Eisen's “Eesti rahvanali” (1909)

Most of the targeted groups come from the periphery of the country, preferably from the islands. The two bigger islands have had, in fact, a long-lasting joking relationship, which has by now become a source of pride and local self-identification (e.g., Roosa 2016).

Language-related matters provided a well-established source of laughter, as in the following joke from Hiiumaa):

A travelling worker from Russia went to Hiiumaa. Others called upon a Hiiu man who had been in the Russian army to talk with him in Russian, but the Hiiu man didn't know a word. The others asked him: "You said that you were fluent in Russian in the army!" The soldier replied: "So what-I was fluent there, but they don't let you bring anything back with you. They took everything back: the gun, the backpack and even the Russian language!"

(Eisen 2002g [1909] No 279: Hiiu soldat [Hiiu soldier]. J. Ratas, Lõve village, South Estonia)

Again, most of the targets of any jokes were given ethnic labels, which once again shows how the semiosphere was organised along the borders of ethnic categories.

\subsubsection{Soviet and early post-Soviet jokes}

Inside Estonia, dialectal differences continued to exist in Soviet times (and do exist even today), but mocking on the basis of ethnicity and its dialectical markers gradually disappears in the material after the 1960s and 1970s. By the 1990s, all small ethnic groups within Estonia merged into a common group of "Estonians" or "us", with the main protagonists identifying themselves as "a man". Only 26 percent of the jokes can be identified as mocking an ethnic group.

One of the few places where Estonians were still mentioned as a nation were the threenation jokes. Three-part anecdotes about an Estonian, a Russian and a German testing strength and wit present a special case: it is a subtype especially popular in Soviet times and particularly among schoolchildren. Jokes about Estonian-Russian-German or the typical three nation joke with either Estonian or Russian in the last slot were the prevalent subtype of ethnic jokes in the 2007 school lore collection. It is important to bear in mind that the German remains in the most insignificant middle position, but due to frequent, almost automatic 
mention is still very visible in the picture. The winning nation is not always the smartest one. These are often jokes with scatological allusions: the contestants have to climb stairs without defecating, or cross a bridge without blowing their noses, etc. The "winner" is then the one who manages to pass the test, but more than being delighted in his obscene victory, children laugh at the dirtiness of the mock hero-who is, very frequently, the Estonian himself, whose victory is often smelly, strange, or awkward. The continuing popularity of the three nation joke also indicates the heightened interest in the local target, the fellow Estonian (Tuisk 2010):

A Russian, a German, and an Estonian are stranded on a desert island when they find a Genie. Everyone is granted one wish. The Russian wants to get home to Moscow and a case of vodka bottles. The German wishes to go home to Berlin and asks for a prettier wife. The Estonian asks for a lot of beer and his two friends back

(http://huumor.nutiteq.ee/Category:Joke)

A Russian, a German and an Estonian are in prison. The one who can stand the smell of a camel for the longest time, will be freed. The German manages to stay there for some minutes and then rushes out, the Russian for some hours. The Estonian has stayed in the tent for some time already when the camel rushes out, screaming, "I can't bear the smell any longer!"

(http://huumor.nutiteq.ee/Category:Joke)

The most popular joke target in the second dataset is instead the Chukchi, the pan-Soviet stupidity paragon. All over the Soviet bloc, people told the following jokes:

Chukchi asks Vanya [generative name for a Russian man]: "Guess how many reindeer I have! If you guess right, you get to keep both of them.

(Viikberg 1983)

Political jokes dominate in the second dataset. Also, the usual and at first sight quite universal stupidity joke characters are actors on the political stage. Thus, even Chukchis are used to criticise the Soviet failed dreams and miserable daily life:

A KGB agent is walking in the forest and hears a strange noise. He goes towards the sound and reaches a small clearing. In the centre of the clearing there is a tree stump, on the stomp sits the Chukchi and swears terribly. The KGB guy steps closer and asks: "Dear Chukchi, why are you swearing here?"

- "I'm swearing because of the government."

- "Well-well! What government?"

- "The tsarist one."

The KGB agent relaxes and tell him: "Ok, you can do that, " and walks away. Then suddenly he begins to wonder why the Chukchi wants to curse the tsarist government, so he returns. Chukchi is still swearing on the tree stump.

- "Hey, Chukchi, why are you cursing the tsarist government?"

- "Because they sold off Alaska, but not Chukotka [Chukchi territories]!"

(Viikberg 1984)

Russian comes second in the popularity rating of targets. Humorous lore about the Russians has always existed in Estonia and travelling workers and soldiers from Russia were known as characters in the Eisen collections (as we saw in the 1909 example about speaking Russian earlier). But especially during the Soviet period and well into the 2000s, the Russian was among the most important ethnic joke characters. In the case of Russians and Estonians, there is no similarity in language and culture, but geographical adjacency and complicated historical relations combined with the unified joke circulation within the Soviet Union makes 
up for this absence. Jokes were often partly in Russian as that was the original language of the joke - or because that gave a distinct character to the Russian who was the target of the joke:

During the Olympic Games, a Russian and an Englishman stayed at the hotel "Olympia" and happened to share an elevator on their way down. The Russian peed in the corner. The Englishman was offended; he retreated into the other corner and started smoking. When the elevator finally reached the ground floor, the Russian said: "Mezhdu protshem, v Sovetskom Sojuze v liftah ne kurjat. ['By the way, you're not allowed to smoke in the elevators in the Soviet Union']."

(Viikberg 1981)

Among other topics, Estonians used to laugh at the Russians' command of the Estonian language. This feature functioned to bring the target closer to the joke-teller and erased the political power distance, replacing them with a top-down laughter at the expense of a geographically close, economically worse off target that fits neatly into the model of stupidity jokes as described by Davies (1990):

In a shop a Russian makes a great effort to express himself in Estonian. The salesperson sees that he is having trouble with it and encourages him: "Speak in Russian, I will understand."

- "Nu net [Oh, no!]," the man replies, "we had to listen to your Russian language for fifty years, now you have to listen to our Estonian."

(Bitman joke collection 1990s)

In Soviet times, a number of new pan-Soviet targets appeared next to Chukchis and Russians, even though generally ethnic labelling diminished. The borders of "us" and "them" had widened, and besides, all the countries in the Soviet Union shared similar jokelore with similar targets: Armenians, Georgians and other members of the 'friendly union of nations'.

\subsubsection{Post-2007 jokes}

The third set, school lore jokes and internet humour from 2007 onwards, represents the most recent developments in the choice of ethnic targets. The overall share of ethnic targets in all the jokes has diminished even more, reaching barely nine percent. There are groups that have emerged as new targets, connected with the immigration crises of 2015-primarily the Muslims as a general category (there have only been a few activations of this joke target previously, most notably after 9/11 terrorist attacks in New York City). Present-day jokes about people of colour use interchangeable scripts, forming a group of new-Others (immigrants) with a generic category label of "a brown person" ('pruunlane'):

Brown person comes to Estonia and starts looking for work. On the first work interview, the boss says: I'll give you a job, 50,000 Euro a year, a 3-storey house, free dental care and a BMW. Later we'll change it with a Mercedes." The brown person: "Are you kidding me?" Boss: "You started it!"

(Eesti Ekspress, Score, Carl16 7 June 2015 10:34:48)

The brown person goes to the Estonian embassy to get citizenship. They give him a dice and tell him: "If you throw any number from 1 to 5 , you won't get it. If you throw a 6 , you can throw again."

(Eesti Ekspress, Õnne Tulits 3 June 2015 11:04:48) 
However, the most prevalent and colourful character in Estonian present-day ethnic humour is the Estonian himself. Slowness is the main topic of these one-liners (collected by Arvo Krikmann):

Estonians are the wealthiest people in the world, because they are unable to spend their salary fast enough.

Estonian rally drivers are successful because they are unable to raise their foot from the gas pedal while in curves.

In the Estonian version of the game show 'Who Wants to be a Millionaire' there is an additional lifeline-'Write a letter to a friend'.

The Estonian boss asks his Russian secretary to type a little slower because he cannot dictate that fast.

(Krikmann 2007)

Such one-liners were not part of the earlier jokelore layers, but have become popular after the turn of the century. Arvo Krikmann described them in his 2007 paper delivered in Rhode Island ISHS conference. Side by side with these witty remarks (rather than classical canned jokes), also slightly longer jokes exist:

Two Latvians are talking:

- "Look, there's a Lithuanian standing over there!"

- "No, that's not a standing Lithuanian, that's a running Estonian."

(Eesti Ekspress, http://ekspress.delfi.ee/elu/milline-on-parim-nali-eestlaste-kohta?id=71608885)

Christie Davies has pointed out that the slowness jokes could be a borrowing from the Swedish-Finnish joking relationship of the 1980s and earlier, when the Swedes (although a minority in Finland) highlighted some essential differences between the Scandinavian and Finno-Ugric ways of life (Davies 2016). The Russians in turn took inspiration from the slowness script and invented their own tradition, targeting a more familiar Finno-Ugric nation. Another equally well-argued hypothesis comes from Arvo Krikmann (2007), who states that the slowness joke was a Russian joke made at the expense of the Finns, so it could have been this image that initiated and mediated the process of the further southward expansion of the slowness stereotype in Russian jokelore, until Estonians took over the role of the emblem of slowness.

There are many jokes about particular character features-subservience, tacitness and excessive conscientiousness of Estonians - that are among the most prevalent ones:

God was fed up with Estonians for not being able to stand up for themselves and did a little test. He summoned all the Estonians and said: "You will all be hanged tomorrow!". Silence. He repeated. Still silence. On the third time he yelled: "Did you get me, you will all be hangedtomorrow!" From the back row a timid voice asks: "Do we have to bring our own rope or will that be available here?"

(Eesti Ekspress, jumala nali 3 June 2015 09:57:21)

How to kill an Estonian?

No need to do anything, just give him 10 acres of land and he will work himself to death.

(Eesti Ekspress, ab, 3 June 2015 15:01:55)

Humour has taken on an increasingly visual format. Especially in the material that comes from social media it is 90 percent visual and the punch-lined joke format seems like a thing from yesterday. In humour-dedicated websites, e.g., meeldib.ee, jokes form 42.6 percent of the whole site content - slightly more than in the case of social media-whereas visual posts are in the majority, 58.4 percent. Online media has brought visuality to the fore, and this 
applies not just for humour. Visuality is often central to the message of the humorous image; although it is mostly the accompanying text that delivers the details and cultural adaptations made to bring the humour closer, some general clues are hidden in the picture (wearing typical clothing, skin colour, etc.). Visual online humour (memes) tends to be political and topical in the case of Russians (e.g. the pictures using the image of Stalin and details on grim history), but also the generic category of refugees, people of colour and Muslims. Humour remains neutral in many other cases where we can perhaps say that ethnicity is indeed neutralised [Boxman-Shabtai \& Shifman 2015] — Chinese, Finns, Latvians).
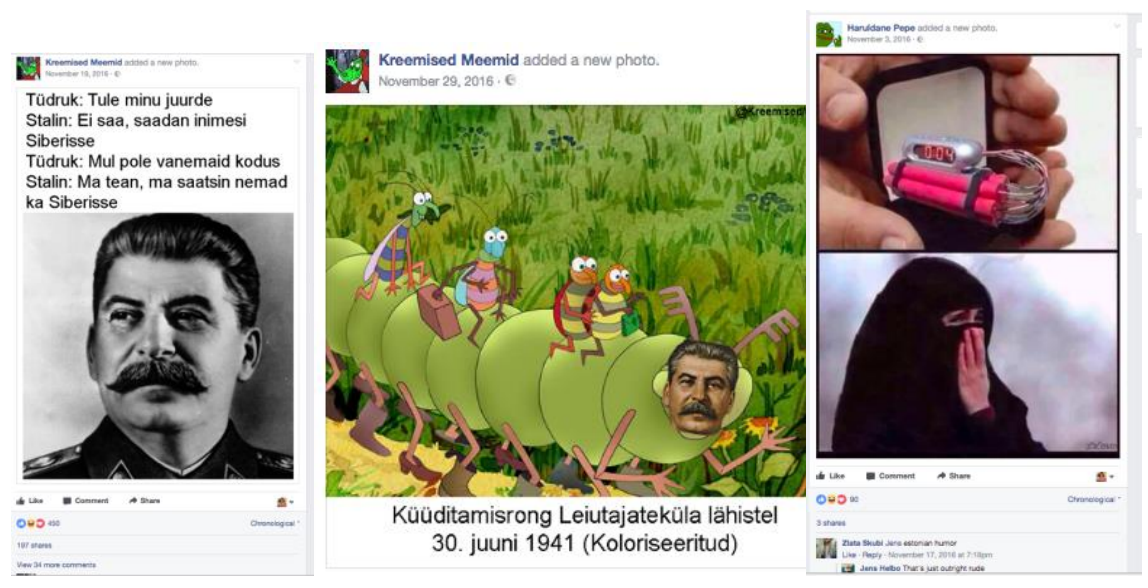

(1) Girl: Come to me! Stalin: No, I can't, I am sending people to Siberia. Girl: My parents are not at home! Stalin: Yes, I know, I sent them to Siberia too. (2) Deportation train near the Gadgetville, 30 June 1941. Colourised photo. ('Leiutajateküla'-the imaginary village in a famous Estonian children's book) (3) Marriage proposal. (Kreemised meemid, Haruldane Pepe)

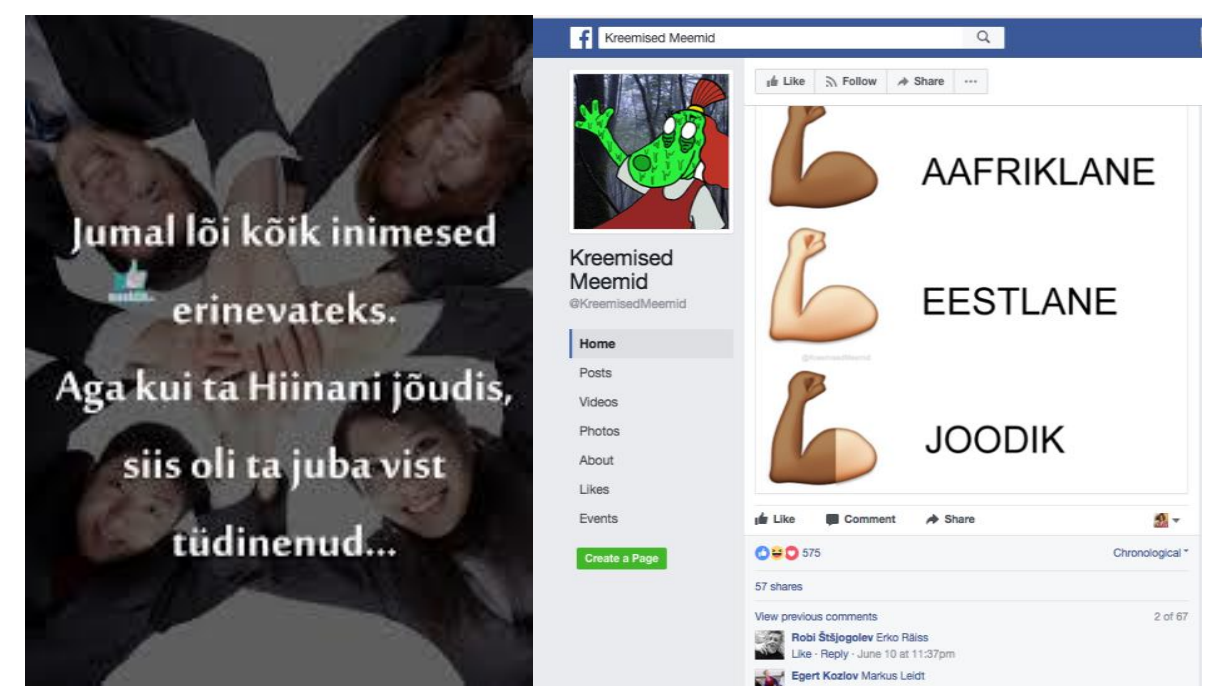

(4) God created all people different. When he reached China, he must have become bored (5) African / Estonian / drunkard (referring to the typical sunburn of people who get drunk in the open air). (Meeldib.ee, Kreemised meemid) 


\begin{tabular}{|l|l|}
\hline English & Estonian \\
\hline $\begin{array}{l}\text { Excuse me, may I disturb you for a } \\
\text { second? }\end{array}$ & Kle... \\
\hline It's you! How lovely to see you! & Tsau! \\
\hline How are things with you? & Mis toimulb? \\
\hline $\begin{array}{l}\text { Excuse me, I didn't quite catch } \\
\text { what you were saying? }\end{array}$ & Möh? \\
\hline $\begin{array}{l}\text { Sorry for bumping into you like } \\
\text { that. So terribly clumsy for me. }\end{array}$ & Ehh? \\
\hline
\end{tabular}

(6) Ponting at the briefness of the Estonian language and the taciturn people. (Meeldib.ee)

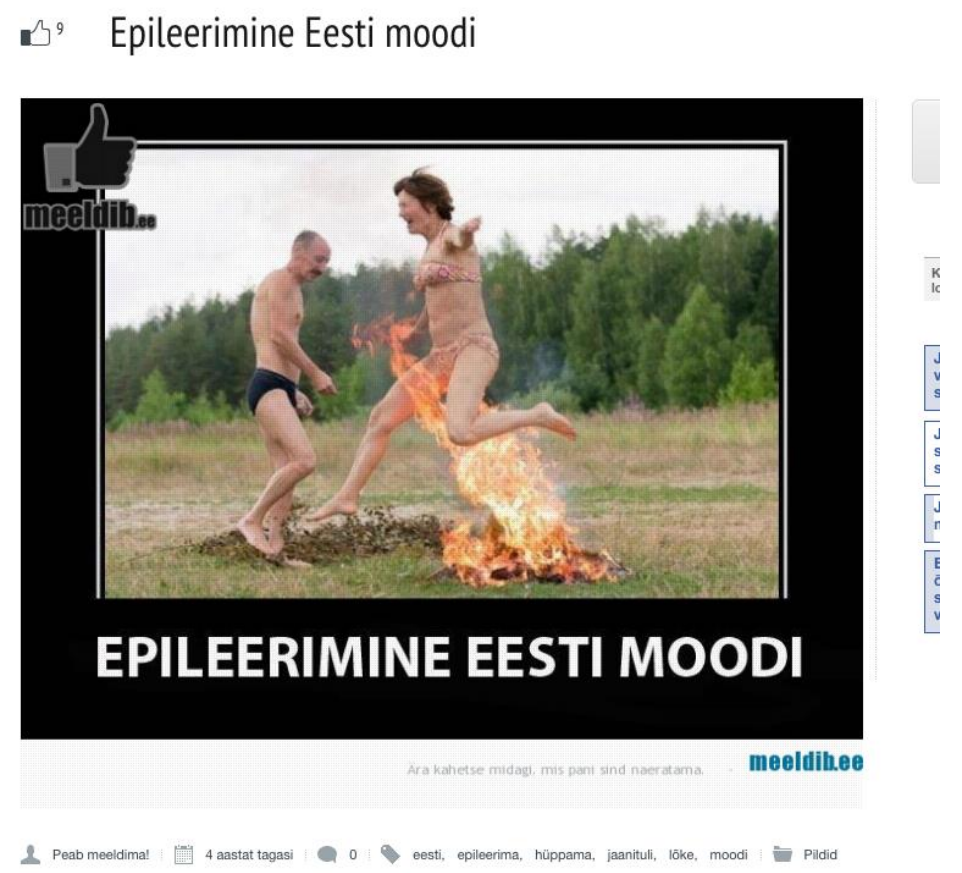

(7) Epilation-Estonian style (referring to the Estonian Midsummer night's eve activities of jumping over the bonfire). (Meeldib.ee)

\subsection{Belarusian data}

The comparative data from Belarus comes from folklore archives and published joke collections as well as the internet. Belarusian folklorists began collecting jokes and other humorous folklore in the second half of the 19th century. Some of them (e.g., Vladimir Dobrovolsky, Aleksander Serzhputovsky) did not distinguish between jokes and fables and published them together in their folklore collections (Dobrovolsky 1891; Serzhputousky 1911). Others dedicated special chapters to jokes in their folklore collections. One of the first to document Belarusian jokes was Evdokim Romanov in the third volume of his "Belarusian Anthology" (Belorusskij Sbornik) in 1887. He listed eight texts under the title of "humorous dialogues". Pavel Shein published 39 jokes in the second volume of his "Materials for the Studies of the Ways of Life and Language of the North-Western Region Russian population" (Materialy dlya izucheniya byta i yazyka russkogo naseleniya Severo-Zapadnogo kraya) (1893). The most systematic of these early collections of jokes was published in Polish by Michał Federowski in 1903. One of the volumes of his monumental work "Belarusian people 
in Lithuanian Rus: Materials for Slavonic Ethnography collected at 1877-1894" (Lud białoruski na Rusi Litewskiej: materyały do etnografii stowiańskiej zgromadzone w latach 1877-1894) was entitled "Fables, parables and folk legends from the area of Vawkavysk, Slonim, Lida, Navahrudak and Sokółka” (Baśnie, przypowieści i podania ludu z okolic Wołkowyska, Stonima, Lidy, Nowogródka i Sokótki) and consisted largely of humorous texts (446 in total). The texts are arranged according to their topics. One of the chapters is dedicated to ethnic humour and contains 157 texts. Not all of them can be labeled "jokes": some of them have a structure that is close to the fable, while others are humorous poems. Regardless of the lack of formal uniformity, Federowski's collection is extremely important because it was the first attempt to organize and classify a considerable body of Belarusian humorous texts.

Apart from the folklorists' and ethnographers' publications, jokes also appeared in some of the early 20th century newspapers (for example, at the calendar published by "Nasha Niva" in 1910). A small non-academic joke compilation was published in 1915 under the title "Belarusian jokes" (Belaruskija zharty). The jokes of this joke book were more "modern" in their content and structure than the ones in abovementioned folklorists' collections.

In Soviet times, a lot of jokes were published in the satirical magazine "Vozhyk" ["A Hedgehog"]. There were also several joke collections compiled by professional linguists and folklorists (e.g., Byaspaly 1970; Gilevich 1983). The most comprehensive collection of Belarusian jokes was published by Anatol' Fiadosik (1984, second edition 2005). The second edition features 1127 jokes divided into two parts: pre-Soviet jokes (683 texts) and Soviet jokes (444 texts). Fiadosik's collection includes many of the texts published previously by other folklorists, but does not represent all of them. The problem with these joke collections was that they were heavily censored and did not feature the same jokes that could be found in oral circulation (Mel'nichenko 2014: 34). For instance, they almost totally neglected ethnic jokes. The few ethnic jokes that nevertheless got to print in Soviet times were the variations of earlier jokes about the same targets that were popular in pre-Soviet times. For example, one of such jokes tells a detailed story of a Gypsy who is cunningly exploiting the generosity of a Belarusian peasant (Byaspaly 1970: 88-89). Both the content and the form of this joke (that resembles a tale more than a canned joke) was 'outdated' at the time when the book was published. Soviet folklorists tried to focus on social rather than ethnic targets when they compiled the joke books. Many of the jokes revolve around stupidity of a nobleman or a priest, but few mention ethnic 'others'. This was in line with the idea that all the nations residing in the USSR have merged into a single "Soviet people". The folklore of all the peoples of USSR was thus considered "a unified poetic art of the Soviet people" (Chicherov 1959: 500)

The jokes that circulated orally in Soviet times were mostly published after the collapse of the USSR. For example, many of the jokes collected in late Soviet times were published in the early 1990s in the joke anthologies compiled by the newspaper "Chastnyj detektiv" [A Private Detective] (Luchshie anekdoty...: 1994).

A Belarusian collection of contemporary (post-Soviet) jokes is yet to be compiled. Some of the jokes collected by folklorists still await publication (e.g., Uladzimir Sysou's field notes from Kalinkovichi district), while most of the verbal and visual jokes are aggregated on the internet. The crucial issue is that it is now very problematic to define the ethnic identity of many of these texts. As modern Belarusians communicate predominantly in Russian, many of them share their humour with other Russian speakers. Thus, it is somewhat difficult to attribute many of the jokes that circulate throughout the web to Belarusians alone. At first glance, jokes and memes in Belarusian can stand out as exceptions, but a deeper analysis shows that some of them are also translated from Russian. In the present study we mainly rely on joke threads on Belarusian forums (talks.by, forum.onliner.by) and other Belarusian 
online media and jokes from social media groups that explicitly identify themselves as Belarusian: "Jokes in Belarusian" ("Zharty pa-belarusku"), "Jokes in [Belarusian] language" ("Zharty na move").

\subsubsection{9th-early 20th century}

The total number of joke texts of this period from various sources is around 1000, with ethnic jokes constituting about 19 percent. A higher proportion of ethnic jokes is in Federowski's joke compilation: around 35 percent. The most popular joke protagonists are Jews, Gypsies, Russians (they are usually called Moskali in these jokes; the word Maskal' is still used as a pejorative term in reference to Russians), sometimes also Masurians and Germans. These were the nations that had the closest contact with Belarusians at that time. Each of them had their peculiar features and roles. For example, the Russians were mostly cunning soldiers, the Gypsies were hired temporarily to do some agricultural work and were known for their inclinations to steal.

It is curious that while these 'strangers' often appear in the jokes together with Belarusians, the word "Belarusians" is rarely mentioned. When a Belarusian is featured in a joke, he is mostly called muzhyk as opposed to the ethnonyms of other joke characters. For example, Dobrovolsky cites a joke "How myzhyk and a Gypsy sowed money" (Dobrovolsky 1891: 692-693; ATU 1200).

The word muzhyk literally means 'a man' in Belarusian. However, it also has another connotation. Muzhyk was a peasant as opposed to the nobility. The term also had a certain ethnic flavour. At the end of the 18th century, present-day Belarus became a part of the Russian Empire. Some of the members of the nobility accepted this incorporation and swore an oath of allegiance to the Russian Empire. Moreover, Russian authorities also encouraged the migration of Russian nobility to the Belarusian lands. These two groups of the nobility considered themselves Russian, spoke Russian and adopted (or preserved in case of the migrants) Russian culture and the Russian Orthodox religion.

Nevertheless, a large group of the nobility opposed the incorporation into the Russian Empire. They pursued the idea of restoring the First Rzeczpospolita that was a commonwealth of the Grand Duchy of Lithuania (that included present-day Belarus) and Poland. This part of the nobility considered themselves Polish, spoke Polish and were mostly Roman Catholics.

What both these groups had in common was their disdain towards the lower classes of the population who were mostly peasants. Their language (which was the basis of modern Belarusian language) was called muzhycki and was considered appropriate only when spoken to peasants and servants, but not among themselves. Therefore, the term muzhyk was in many ways synonymous to a Belarusian, but it also had a strong social connotation. Such an identification of Belarusian with peasantry continued in the first decades of the 20th century (Astapova 2015: 17).

Another kind of ethnic joke of that time is the one about distinct groups within Belarusians. The most well represented group are the Poleshuks, the inhabitants of Polesie. Polesie is a swampy region in southern Belarus and northern Ukraine. Due to the peculiarities of its landscape, it was difficult to access many of its villages throughout a significant part of the year. Consequently, its inhabitants had very distinct culture and dialect which was sometimes even considered to be a separate language (on the Polesian language see, for example, Chodakiewicz 2012: 493). The landscape of Polesie slowed down the modernization of this region. This resulted in the fact that Poleshuks became typical butts of stupidity jokes: 
Two Poleshuks were going along the road. Suddenly they saw a sickle. But they did not know what it is. So they stood and were looking at it, puzzled. Then one of them, who was a little bit braver, took it, hung it over his shoulders and quickly went to show it to the people. After walking for a while, he became curious and wanted to take it off. He pulled a little, but the sickle was stuck in the clothes and did not move. He started screaming:

"Oh, hey! Brother, what the hell is this? Help me, or it will eat me!"

The other one ran up to him and wanted to take the sickle as soon as possible. But as he pulled it, he beheaded the other one. That's what happened!

(Federowski 1903: 211-212)

There are also smaller groups among the Poleshuks that become the butts of stupidity jokes. One of these groups are the inhabitants of the village of Markavichy that lies not far from the modern Belarusian-Ukrainian and Belarusian-Russian borders. Russian folklorist and ethnographer Sergey Maksimov cites several jokes about them:

Three Markovcy were going [home] from the haymaking and saw a church: they had never seen such a big building. They went inside and were even more surprised. Everyone wanted to shout, to see if the voice would echo. They started asking for permission.

"It's not allowed", they are told. "It is a house of God, a sacred place".

They asked again: "Let us make some noise [tuknut']"

"If you give twenty pounds of honey per house per year, you may shout".

They agreed. So a special tax called tukovshchina or pogukovshchina ['gukat' means shout] was established.

(Maksimov 1882: 440)

Not only does Maksimov quote this joke but he also gives his reasons why Markovcy became the butts of the jokes. He points out that due to the fact that they live close to the border they do not fully belong to any ethnic group. Moreover, Maksimov argues that Markovcy became the butts of the jokes due to the close proximity of Russians and Ukrainians who are known for their fondness of making jokes (Maksimov 1882: 440).

Another possible reason for the popularity of these joke butts may lie in the fact that due to the specific landscape conditions Poleshuks relied mostly on cattle breeding and hunting rather than agriculture that was the main economic activity for the rest of Belarusian population. In case they did plant crops Poleshuks had to use more archaic ways of agriculture that involved cutting down and burning the trees. That is why they were perceived as backward and unaware of more modern agricultural tools and methods. Moreover, due to their backwardness they are portrayed in jokes as the ones who are unaware of proper ways to conduct religious services and behave in church. It is important to mention that in the 19thcentury Belarusian village a priest was often the only person whose work was intellectual rather than physical. Poleshuks' unawareness of religious rituals and modes of behaviour represents the analogy of mind over matter opposition that lies in the core of many stupidity jokes (Davies 2011: 21).

Like in Estonia, local joke butts in Belarus came primarily from the periphery. However, the share of ethnic jokes in this data set is not as high as in Estonia. It reflected the general situation in Belarusian society at that time where social identification was prevailing over the ethnic one. Ethnic identification was much more prominent among the nobility than among the peasants from whom the jokes were mostly collected at that time.

\subsubsection{Soviet and early post-Soviet jokes}

From circa 3000 jokes from this period that were analysed for this paper, ethnic jokes constitute around 16 percent. Much like in Estonia, ethnic jokes about local outsiders became 
less popular in Soviet Belarus. Poleshuks kept their dialect, but their lifestyle became more similar to the life of other Belarusians. Their land became easily accessible when the wetlands were drained in 1966-1990. Consequently, the differences between Poleshuks and other Belarusians became blurrier.

Three nations jokes were also popular in Belarus. It is curious, however, that a Belarusian is not always featured among the joke protagonists. Many of the jokes show the interaction between a German, a Pole and a Russian or an Englishman, a Frenchman and a Russian. A Russian is normally the one who "wins", but his victory is as ambiguous as the Estonian's in the respective three nations jokes. Some of the plots are almost identical:

An Englishman, a Frenchman and a Russian got to an uninhabited island. Once a bottle was washed off the island's shore. When they opened it, a Genie appeared and said:

"I will fulfil two wishes for each of you".

The Englishman said:

"A sack of money and to return home".

The Frenchman said:

"A woman and to return home".

The Russian stayed alone. He thought for a while and said:

"We had such good company here. [I want] a case of vodka and all of them back here"

(Luchshie anekdoty... 1994: 263).

An interesting comment about the identity of the Russian in these jokes was made by a Belarusian writer and folk humour promoter Vladimir Lipsky. He argued that "a Russian in these jokes is a Russian [rossiyanin], a Belarusian and a Ukrainian at the same time". (Karpovich \& Gil 2008)

Other "pan-Soviet" targets such as Chukchi, Georgians and Armenians and even people of colour are also present in Soviet and post-Soviet Belarusian folklore. Their popularity is evident from the fact that there were even some meta-jokes about them:

A person of colour decided to go to the USSR. His friends try to dissuade him:

"Don't go, they tell jokes about us".

But he went and took a monkey with him. In Moscow he took a bus. An old lady sitting next to him asked him:

"Who are you?"

"I am your joke butt".

"Oh, Vasily Ivanavich², you have changed so greatly! And how has Pet'ka changed!"

(Luchshie anekdoty... 1994: 71-72)

Belarusians, however, are not present among popular joke targets of this epoch. Partly this might be explained by the fact that they identified themselves with Russians in three nations jokes (though sometimes the same jokes are adapted to local context and a Russian is replaced with a Belarusian). If Belarusians appear in jokes independently, they are portrayed as stupid or dirty:

Once a Belarusian was asked:

"How often do you wash your body?"

"Well, once in a half a year".

"That rarely? Don't you feel dirty?"

"I do, but only for the first two months, then the dirt starts to fall off by itself"

(Nichiporovich 1998: 347-348).

A Belarusian is sitting on a tree and cutting the branch that he is sitting on. A man passes by:

"Belarusian, you will fall down!" 
"It's unlikely".

After some cutting he falls down. He gets up and follows that passer-by with his gaze:

"What a sorcerer!"

(Nichiporovich 1998: 348).

The Soviet and early post-Soviet period in Belarus were marked by a high number of ethnic jokes about Chukchi, Caucasians and other ethnic groups that were targeted in other countries of the USSR as well. Due to their close proximity with Russia (unlike in Estonia, this proximity was both historical and cultural and linguistic) it was easy for Belarusians to adopt ethnic jokes about their "great neighbour". The Belarusians do not play a prominent role in these jokes as presumably many of them identified themselves with a "Russian" or "Soviet" ethnic label.

\subsubsection{Contemporary jokes}

In a sample of circa 500 jokes from two popular internet forums (forum.onliner.by and talks.by) and some other jokes from social media posted from 2008 to 2016 the proportion of ethnic jokes is around 17 percent. It is worth mentioning that most jokes posted on these forums are in Russian. This tendency mirrors the general situation in Belarus where only one and a half percent of the population speaks Belarusian at home (Zinovsky et al. 2011: 355). This ratio is higher in social media groups that are dedicated to Belarusian jokes. Social media also has a higher variety of humorous text forms that are mostly visual

However, it is difficult to make a distinction between ethnic and political humour in contemporary Belarusian jokelore. Many of the jokes play with the idea of nationalism that is associated with speaking Belarusian:

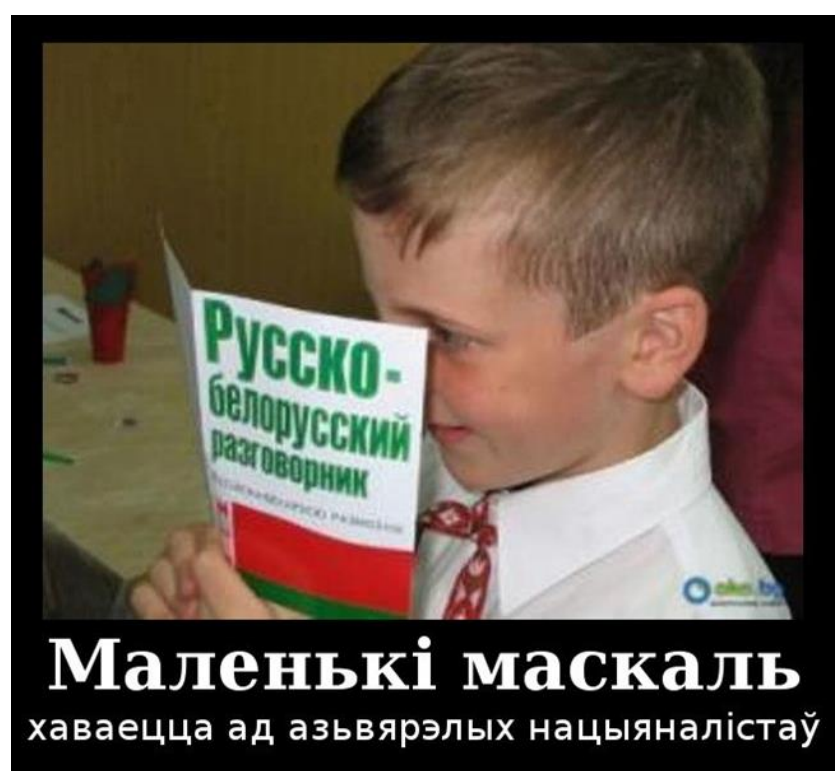

(8) The text: A little Mascal' is hiding from wild nationalists

The thin book the boy is holding reads "Russian-Belarusian phrasebook". (Vk.com/bulbashorg) 
'Belarusianness' is tightly linked to speaking Belarusian:

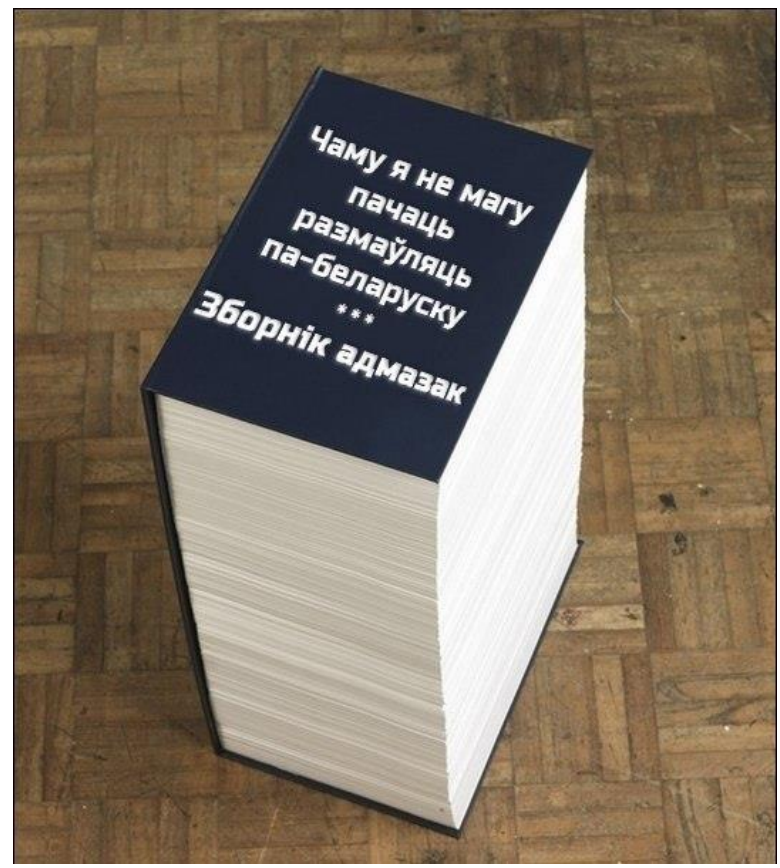

(9) Why can't I start speaking Belarusian $* * *$

An Anthology of Excuses. (Vk.com/bulbashorg)

The most popular topic is Belarusian authoritarian political regime:

If you switch Belarusian [TV] channels at a speed of 25 channels per second, you can read "Everything is fine" on the screen.

(Talks.by)

When are Belarusians offended?

When they are asked: "What's new?"3

(Vk.com/bulbashorg)

Some of the stereotypes of Belarusian character also become the butts of the jokes. The most prominent ones are submissiveness, suffering and passiveness:

A Russian was sitted on a bench which had a nail pointing out of it. The Russian sprang up from the bench, crushed it, cursed everyone and left. A Ukrainian sat [on the same kind of bench]. The Ukrainian stood up, pulled out a nail, took it and left. A Belarusian was sat there too. The Belarusian was sitting and sitting, ouching and ouching and then said: "But maybe it ought to be this way?"

(Padsluhana Belarus)

A dog comes to the Belarusian-Ukrainian border, limping. She is barely alive, very thin, the shreds of fur stick out. She asks the Ukrainian border guards:

"Guys, it's a matter of life and death: let me into Belarus, I'll be happy there".

The border guards shrug and let her go to Belarus. In a year they see the same dog. It is well-fed, fat and well-groomed. They are even more shocked and say:

"We won't ask you what has happened to you during this year and how they treated you. Just tells us: why are you coming back?"

"Guys, everything was superb: they gave me food and drinks, cared about me, encouraged me to lick the butts of other dogs. But there was one thing I could not tolerate..." 
"?"

"They did not allow [me] to bark".

(Forum.onliner.by)

In this respect Belarusians are very similar to Estonians in their self-representations in contemporary jokes. Some of the jokes (like the one about hanging and bringing a rope along) exist in Belarusian folklore as well and likely migrated to both Estonia and Belarus as a variant of earlier Soviet joke (see Mel'nichenko 2014: 448).

There are also new local targets such as the dwellers of Auciuki and Sporava. However, as joke targets they are mostly constructed (or reinvented) by certain Belarusian intellectuals rather than by vernacular tradition. Many the jokes about them are adapted from other ethnic or non-ethnic jokes.

A Sporavec [a man from Sporava] buries his mother-in-law. The coffin is accompanied solely by tiptoeing men.

A passer-by asks:

"Why is the deceased lying on one side?"

"Keep quiet, or she might wake up", the Sporavec whispers.

(Mikhnevich et al. 2001: 5)

A lecturer from the regional center delivers a lecture in Auciuki. After the lecture he asks if there are any questions. An Auciukovec [a man from Auciuki] asks:

"Have you seen who took my hat during your lecture? Everybody was sleeping in the lecture hall apart from you. Maybe you have seen who took it?"

(Lipsky 2008: 57)

Apart from Belarusians, there are a lot of other ethnic butts in contemporary Belarusian humour. Some of them are new to Belarusian context (people of colour, Somalis, Australians) while others are more familiar (Russians, Ukrainians and Chukchi). Visual ethnic jokes in Belarus also react to the contemporary political events: 


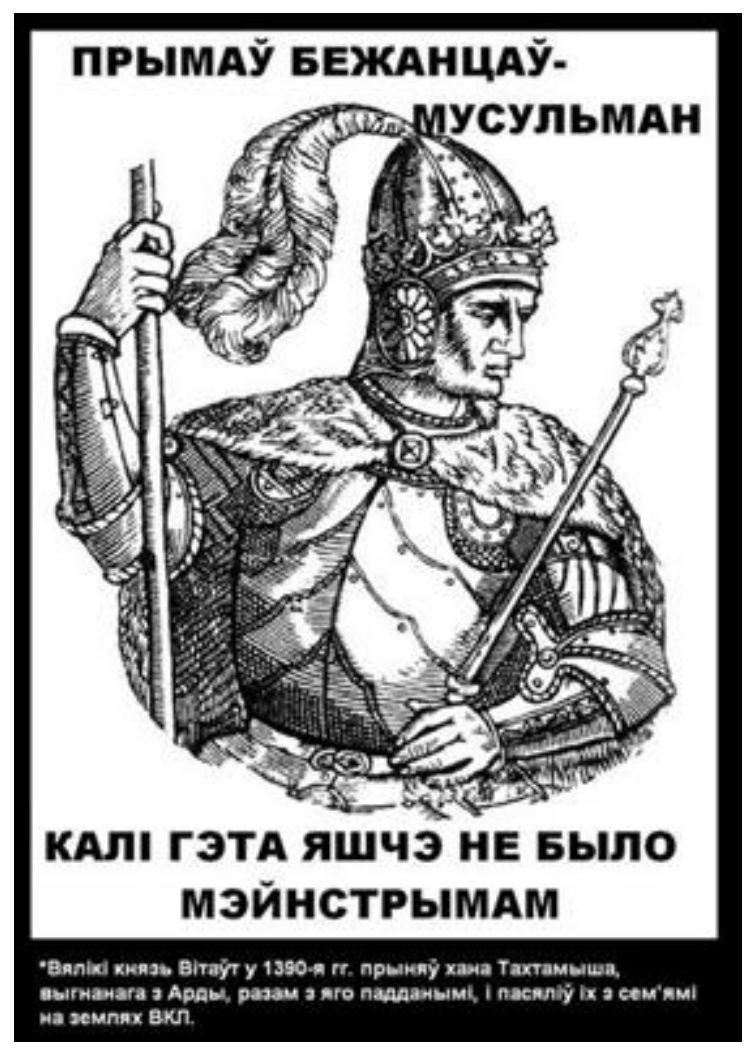

(10) Accepted Muslim refugees before it became mainstream.

In 1390s the Grand Duke Vitaut accepted khan Tokhtamysh who was expelled from Golden Horde and settled him and his subjects in the Grand Duchy of Lithuania.

(Vk.com/bulbashorg)

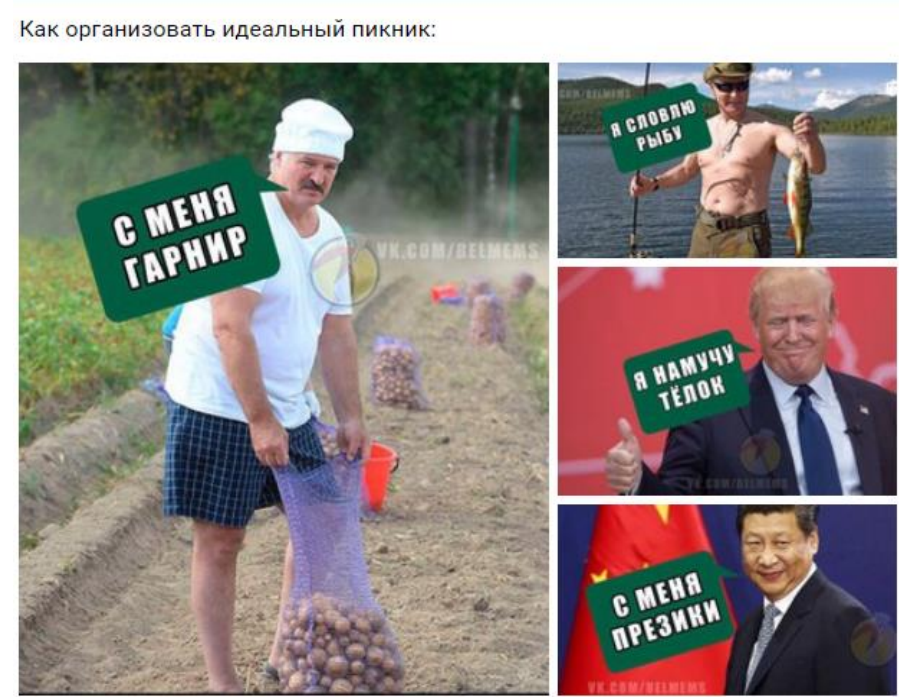

(11) How to make an ideal picnic

Belarusian president Alexander Lukashenko: I will provide the side dish ${ }^{4}$.

Russian president Vladimir Putin: I will catch some fish.

American president Donald Trump: I'll get some chicks.

Chinese president Xi Jinping: I will provide condoms ${ }^{5}$. (Vk.com/bulbashorg) 


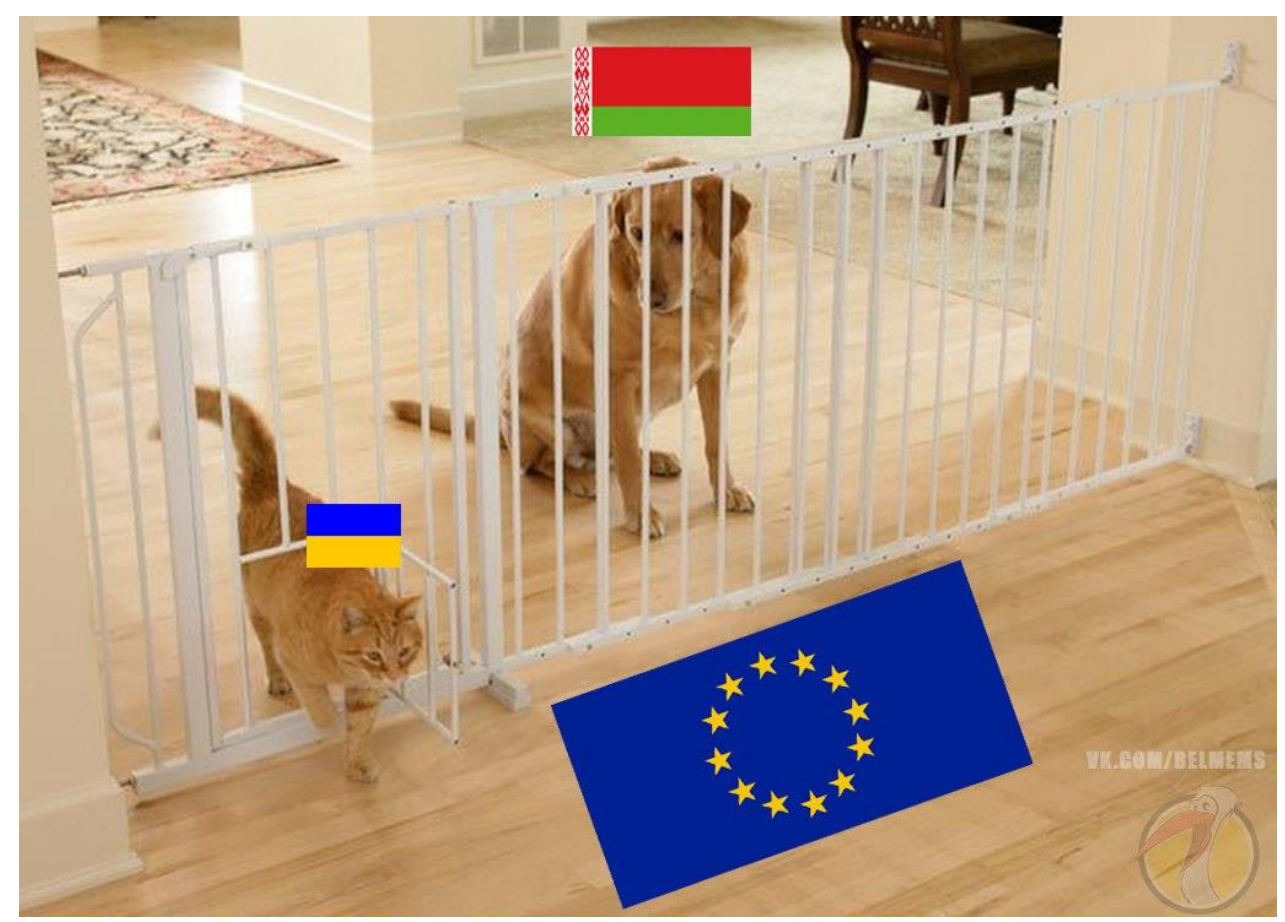

(12) Some of Belarusian memes do not mention Belarusians verbally, but show certain visual elements (flags, elements of national costume, potatoes) that help to identify Belarusians as ethnic targets. (Vk.com/bulbashorg)

Much of the modern ethnic humour in Belarus is connected to current political events. This is especially relevant for the humour about distant ethnic groups. Most Belarusians do not have any immediate contact with them and therefore make jokes on them based on their image in mass media. However, Belarusians themselves are also often regarded as a political rather than ethnic entity.

\section{Discussion and conclusions}

Ethnic jokes have grown less frequent in the course of time in Estonia. One of the reasons for the larger proportion of ethnic jokes in the earliest Estonian material could be that the main collector of ethnic jokes at that time, M.J. Eisen, preferred ethnically located jokesespecially about ethnic groups within Estonia - in his collections and dismissed the jokes that followed the "new style" and were shorter and not assigned to one ethnic group. In the foreword to one of his published joke books, he noted that the jokes that can be read in newspapers are completely universal and as such should attract no interest from the readers (Eisen 1909). Ethnic labelling was in the 1900s more widespread also due to geographical isolation-e.g., on the islands-groups of people developed idiosyncrasies that provided incongruence for the joke-tellers. This grew less important as transportation was readily available and people travelled more. In the present day, community boundaries are pushed further and increased cross-cultural communication emphasises people's similarities rather than differences. Therefore, ethnic labelling becomes secondary and gender specification (man/woman; name) is used instead. A thorough study on Finnish wellerisms (JärviöNieminen 1959) from the period 1880-1955 points to the same tendency: The use of ethnic names is on the decrease.

In contrast, the proportion of ethnic jokes remained relatively stable in Belarus. This can be explained by the fact that ethnic identification in pre-Soviet and Soviet times in Belarus was somewhat blurry. Consequently, many joke targets (especially the Belarusians 
themselves) did not have any ethnic labels. While local peripheral group of Poleshuks was noticeable in the 19th and early 20th century, in Soviet time Polesie lost much of its peculiarity. Moreover, Belarus experienced a great influx of Russian jokes. Ethnic labelling was most visible in three nations jokes; other jokes used gender, social or political identification of the joke targets.

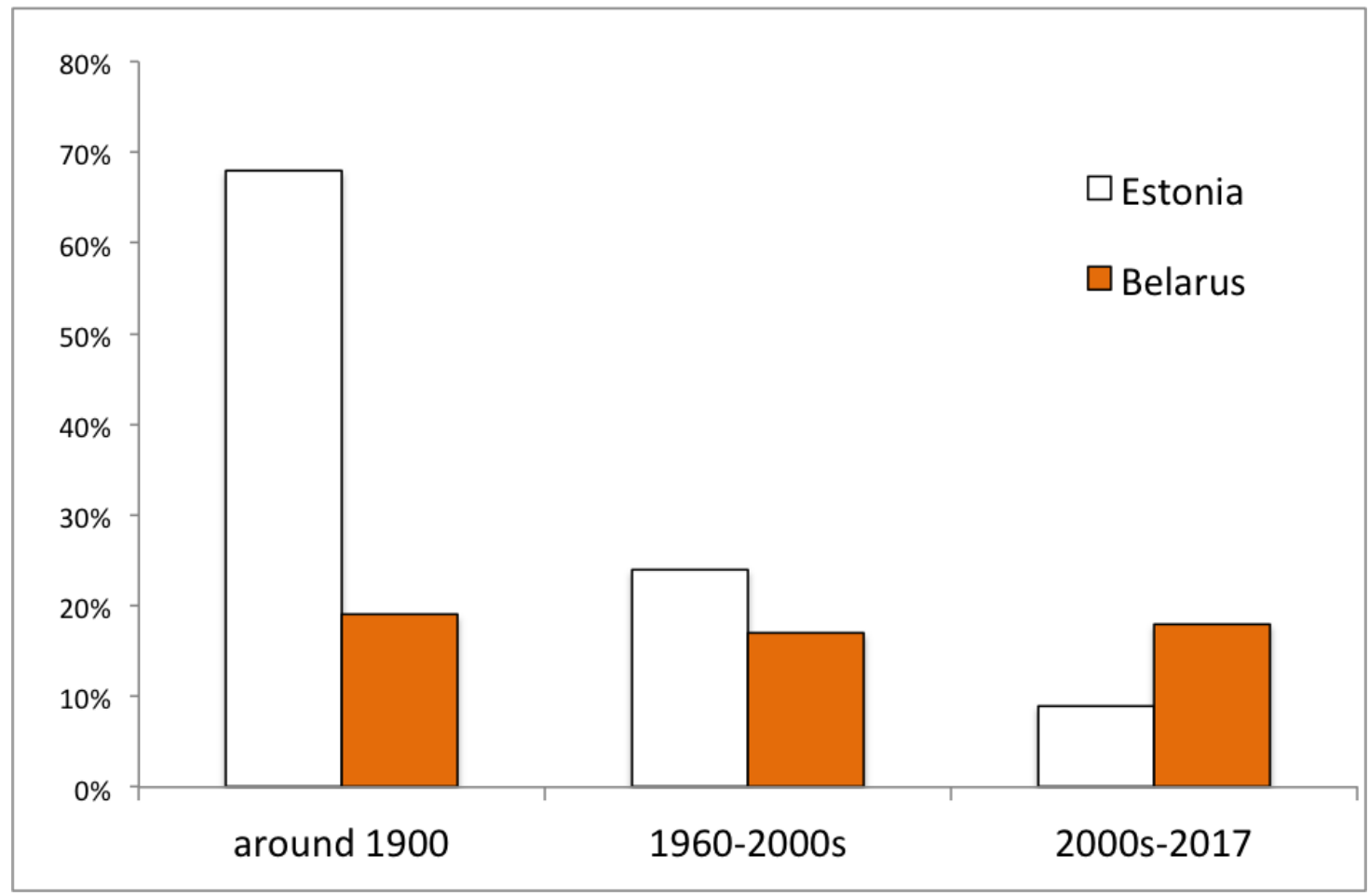

Figure 2. Share of ethnic jokes in the material, Estonia and Belarus

In Estonian material that covered nearly a century of joking, the development is from geographically closer to more far away ethnic groups and then to ourselves and closer neighbours again. The same tendency can be observed in Belarus as well, though neighbours are still more targeted than the locals. This is due to the fact that Belarusians might identify themselves with other ethnic labels (e.g., Russians in three nations jokes): 


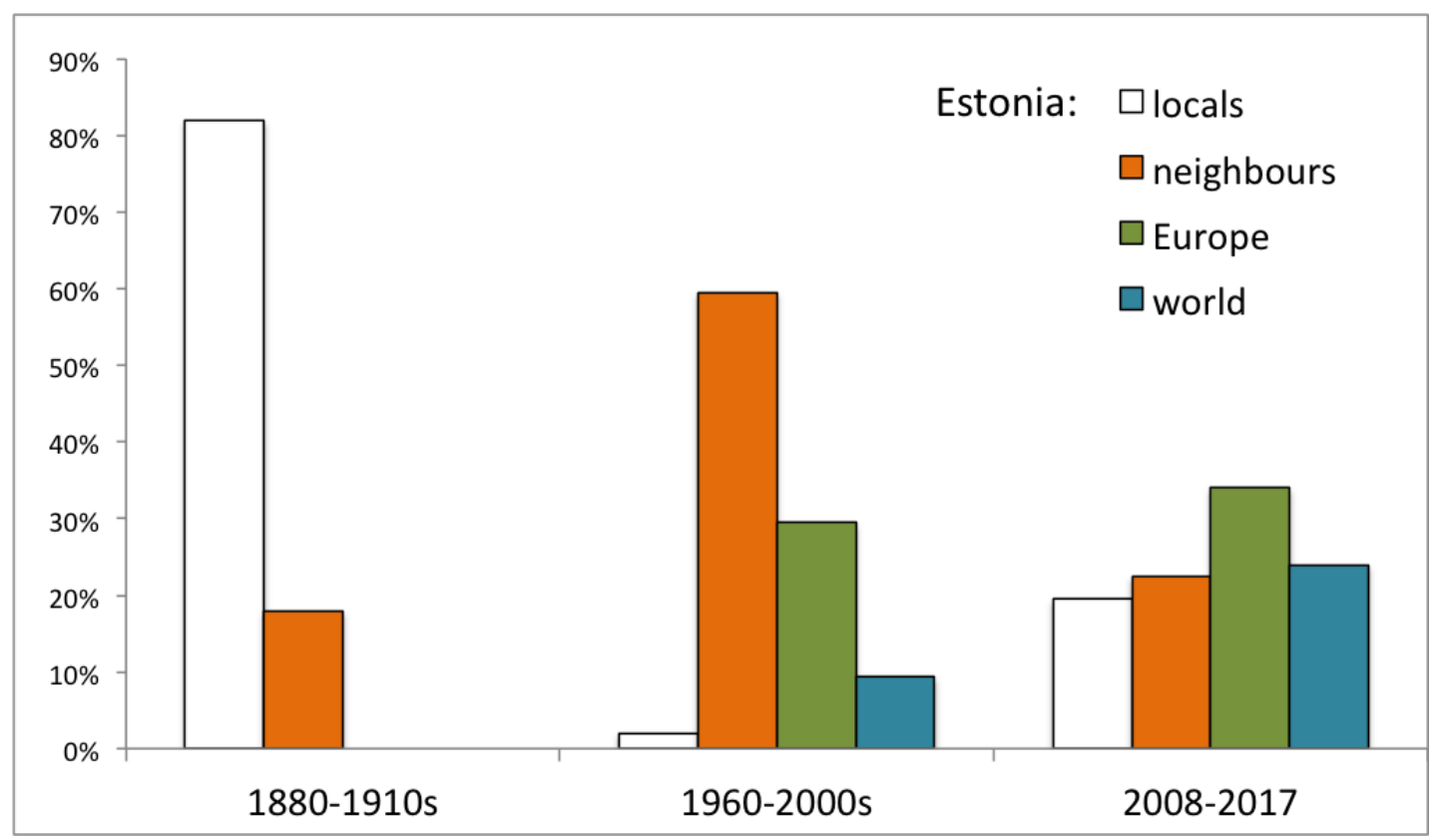

Figure 3a. Ethnic joke butts distribution inside the category of ethnic jokes in Estonian data set

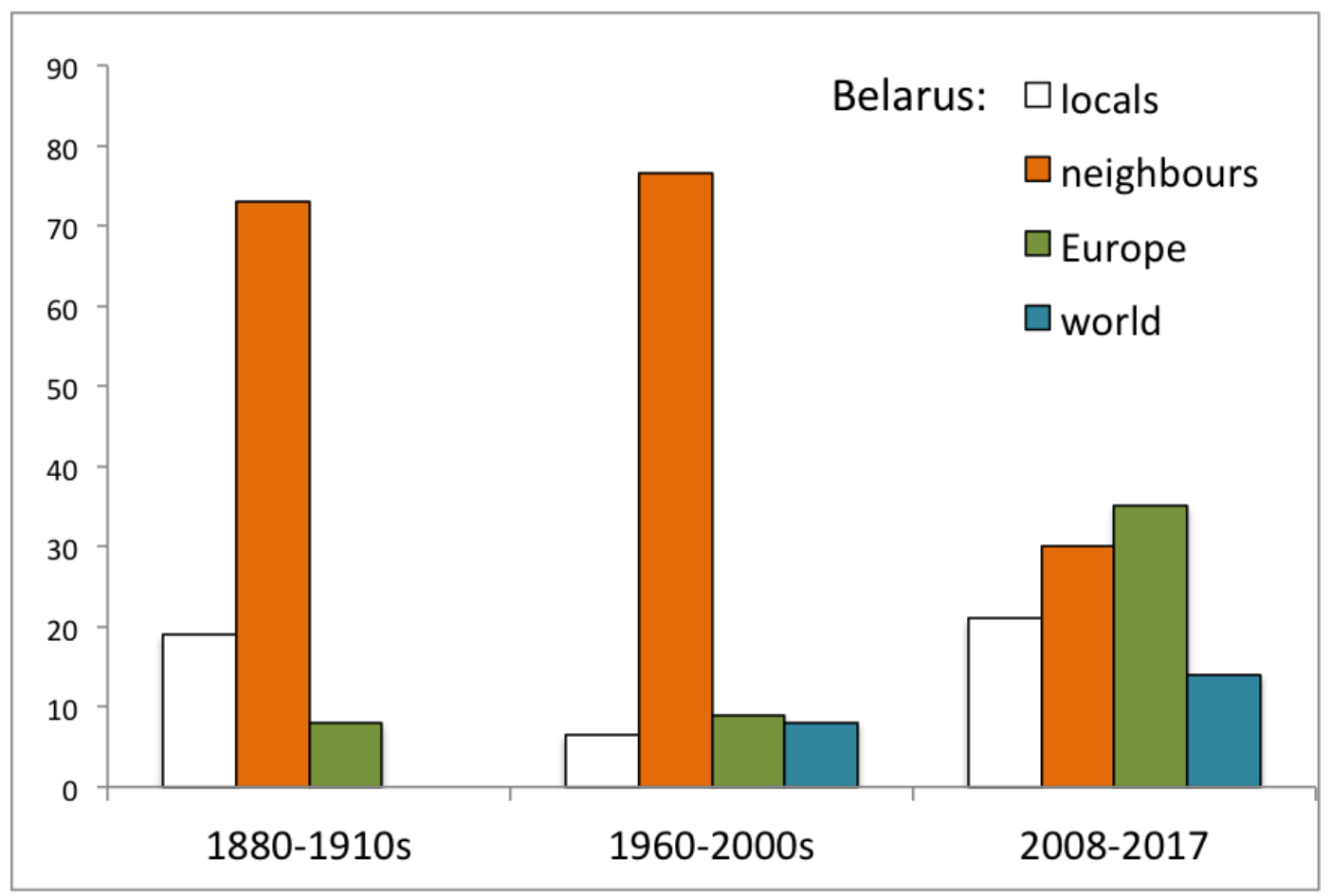

Figure 3b. Ethnic joke butts distribution inside the category of ethnic jokes in Belarusian data set

Apart from still occupying an important place in the three-nation joke, the jokes about Russians declined in Estonia together with the fall of the Soviet Union; in Belarus many jokes about Russians became political rather than ethnic. Together with that, jokelore about local groups - Estonians in Estonia and Belarusians in Belarus - and in the Estonian case, the smaller dialectic divisions went through a rise. 
People of colour as a target form a generalised category and are present in visual ethnic humour. Estonians themselves, as well as Latvians, Muslims, Chinese and Finns feature in the memes too. In the Belarusian case, memes feature mostly Russians, Ukrainians, Americans, Muslims and Chinese. The former suggestions (Laineste 2005) about the constant widening of the circle/selection of ethnic targets does not hold true here because the multiplicity of targets in jokes (published collections of the 1990s or internet collections in the 2000s) is now gone and some particular local groups stand out. Hence, we can say that first, the favourite Estonian and Belarusian ethnic targets are the locals and close neighbours (and also other European joke butts in Belarus) - and second the new groups with recently established closer contacts like the 2015 (Syrian) immigrants (these jokes are more prominent in Estonia than in Belarus). People of colour are grouped into one single category with the other visually different Others who immigrated to Estonia and threaten the established social order - as jokes show the situation. Given that there was no massive immigration to Belarus, the jokes about Muslims, Chinese and other "exotic" ethnic groups are set outside of Belarus (usually, in their own countries).

Ethnic targets in jokes are a conscious choice, dictated by relevant societal issues (relations with closest neighbours, the absurdity of the Soviet politics, the quest for a newor re-discovered old - national identity, etc.). The changes that jokes have gone through can be ascribed to the general attitudes of nations towards themselves and the opposition to a relevant "other". However, the presence of political pressure has, in this case, muddled up the emic target choices (that can be encountered, for example, in the earlier material collected by Eisen in Estonia and in Soviet joke books and satirical magazines in Belarus). This seems to be a common trait of the choice of targets in ethnic jokes in several other East-European countries as well. At the same time, the focus has always been on the relevant issues: in the earliest times described here, the main focus were the neighbours or the inhabitants of the neighbouring parish. During Soviet times, people were most concerned with politics and ethnic groups responsible for political oppressions, and as the borrowed Soviet jokes were critical towards the regime, there was no need for more elaborate and free running alterations or modifications of these jokes. After the countries regained independence from the Soviet regime, the main focus was the quest for a new identity, which in Estonia's case found expression in a rejection of old Soviet jokes and even turning back to 19th-century modelsat least in terms of target choice. In the Belarusian case, this quest for new identity was not as evident and many Soviet jokes were adapted to a new context. Ethnic identity is also tightly connected to political position in contemporary Belarusian ethnic humour. The creation and alteration of traditions is thus closely connected with everyday reality and the social and political context influencing this.

Ethnic targets are, however, not popular in jokes any more (now steadily around ten percent of all jokes are ethnic); ethnic labels have become more rare both in jokes as well as visual humour, being replaced by gender, profession or other ways to define the target.

Our findings contest some of the latest results in ethnic humour research, stating above all that the category of ethnic jokes is falling in popularity. In the most recent material, however scarce, locals are main targets, regardless of globalisation. The local targets are more often shown visually than distant others-memes show Estonians and Belarusian, respectively, most often. Online humour tends to be visual and relies on language play. Other points that Kuipers and van der Ent (2016), as well as Boxman-Shabtai and Shifman (2015) have suggested, are reinforced, for example that a meta-level approach to producing humour is often used. Memes and jokes play with the stereotypes, targeting implicitly both the targets mentioned in the text or image as well as the people who believe such stereotypes are true. On the whole, ethnicity is often a non-issue (or uses a playful, benign stereotype, e.g., about 
the weather in a particular country) - it is backgrounded in the joke. This is manifested also in the relatively low share of ethnic humour in general.

Together with the content of ethnic humour, form needs attention as well. The development of the short and punch-lined format as a result of commodification of the old folk joke (Wickberg 1998; see also Kuipers 2002 on the influence of the internet on jokes) can, for example, be followed in the early Estonian material: jokelore from 1890s contains both long joke tales and short, punch-lined jokes (Eisen 1909). Belarusian material shows a development towards less detailed, shorter texts as well (Famichova 2011). Even though scholars have formulated quite different perceptions about the origin and age of the punchline (for an intriguing discussion see Krikmann 2008), the fact is that jokes started to be shorter and more concentrated at the turn of the 20th century. In the present day, both jokes and joke tales have fallen in popularity. The huge joke collections of the first post-Soviet years have been replaced by humour that has a visual component (next to — or instead of - the verbal one) it is usually best to look at a joke tradition as widely as possible: folk collections, published material in the press, comedy shows, caricatures-and not all of them and everywhere can be explained by the same mechanisms. They also change more slowly than society as a whole, which makes seeing connections more difficult. We have to attempt to look at phenomena diachronically to be able to-or try to-grasp the patterns and mechanisms. Only then can societal changes be seen reflecting in the material.

\section{Acknowledgements}

The study was supported by the Estonian Ministry of Education and Research (IUT22-5), and by the European Union through the European Regional Development Fund (Centre of Excellence in Estonian Studies).

\section{Notes}

${ }^{1}$ A Gypsy makes friends with a wealthy Belarusian man and suggest that they sow their money. At first the Belarusian sows a small fraction of his money and the Gypsy adds his own coins so that they collect three times more than the Belarusian thought they had sowed. Next time the Belarusian sows all his money and the Gypsy collects them secretly at night and tells the Belarusian next morning that the weather was bad and the money is gone. The Belarusian then commits suicide and the Gypsy lives happily afterwards.

${ }^{2}$ This joke also refers to the popular Chapaev joke cycle. Vasily Chapaev was a Red Army commander during the Russian Civil War of 1917-1922. He became an iconic figure for Soviet propaganda after his wartime heroism was made the basis of a popular 1934 film. Pet'ka is one of Chapaev's fictional aides who often appears alongside him in the jokes.

${ }^{3}$ The joke refers to the fact that Belarusian president Alexander Lukashenko has been ruling the country since 1994 .

${ }^{4}$ One of the popular stereotypes about Belarusians is that potatoes are their staple food.

${ }^{5}$ One of the most Common Belarusians' stereotypes about the Chinese is related to their one-child policy. 


\section{Appendix}

\section{Joke sources}

Bitman joke collection, 1990s = Eesti kaasaegsed anekdoodid ['Estonian contemporary jokes'], http://www.folklore.ee/ liisi/o2/. Last accessed October 2017.

Byaspaly, Z. [ed.] (1970). Belaruskiya Narodnyja Zharty ['Belarusian folk jokes']. Minsk: Belarus.

Eesti Ekspress = Eesti Ekspress, 3 June 3 2015, Milline on parim nali eestlaste kohta? ['What is the best joke about Estonians?] http://ekspress.delfi.ee/elu/milline-on-parim-nali-eestlastekohta?id=71608885. Last accessed October 2017.

Eisen $(1895-1910)=$ Eisen, Matthias Johann. Rahva Naljad. Matthias Johann Eiseni raamatud ['Folk jokes. Matthias Johann bisen's http://www.folklore.ee/rl/pubte/ee/vanad/eisen/index.html. Last accessed October 2017.

Federowski, M. (1903). Baśnie, przypowieści i podania ludu z okolic Wołkowyska, Słonima, Lidy, Nowogródka i Sokółki ['Fables, parables and folk legends from the area of Vawkavysk, Slonim, Lida, Navahrudak and Sokółka'] 3. Krakow: Wydawnictwo Komisyi antropologicznej akademii umiejętności.

Dobrovolsky, V.N. (1891). Smolenskij etnograficheskij sbornik ['Ethnographic Anthology of Smolensk'] 1. St. Petersburg: Tipografiya E. Evdokimova.

Forum.onliner.by $=$ https://forum.onliner.by/viewtopic.php?t=8384267

Haruldane Pepe = https://www.facebook.com/Haruldane-Pepe-1834461563449570/?fref=nf

https://vk.com/bulbashorg. Last accessed October 2017.

Kreemised meemid $=$ https://www.facebook.com/KreemisedMeemid/. Last accessed October 2017.

Lipsky, U. (2008). Auciukouskija Shury-Mury ['The Love Stories of Auciuki']. Minsk: Knigazbor.

Luchshie anekdoty, prislannye na konkurs gazety "Chastnyj detektiv" ['The best jokes that were sent to the "Chastnyj detektiv" joke contest']. (1994). Minsk: Redakcyja gazety "Chastnyj detektiv".

Maksimov, S. V. (1882). Belorusskaya Smolenshchina s sosedyami ['Belarussian Smolensk region with its neighbours']. In Picturesque Russia [Zhivopisnaya Rossiya] 3 (1), pp. 429-472. Meeldib.ee = http://meeldib.postimees.ee/; https://www.facebook.com/meeldib.ee/, Last accessed October 2017.

Mikhnevich, G. I. et al. (eds.) (2001). Sporava i sporaucy ['Sporava and Sporava dwellers']. Vol. 2. Brest: AAT "Bresckaya drukarnya".

Nichiporovich, T. G. (1998). Anekdoty pro russkih i nerusskih ['Canned jokes about Russians and non-Russians']. Minsk: Literatura.

Padsluhana Belarus = https://vk.com/wall-56895484_28896. Last accessed October 2017.

Talks.by $=$ https://talks.by/showthread.php?t=14265317\&page $=3$. Last accessed October 2017.

Three nation jokes in Estonia = http://huumor.nutiteq.ee/Category:Joke. Last accessed October 2017.

Viikberg, J. (ed) (1997). Anekdoodiraamat: Naeruga eilsest: Eesti anekdoot 1960-1990 ['With laughter from yesterday: Estonian jokes 1960-1990' ']. Tallinn: Eesti Keele Sihtasutus. 


\section{References}

Astapova, A. (2015). 'Political cartoon at the service of West Belarusian left wing movement: The journal "Malanka" (1926-28)', Journal of Belarusian Studies 7(3), pp. 7-41.

Boxman-Shabtai, L. \& Shifman, L. (2015). 'When ethnic humor goes digital'. New Media \& Society 17(4), pp. 520-539.

Chicherov, V. I. (1959). Russkoe narodnoe tvorchestvo ['Russian folk art']. Moscow: Izdatel'stvo Moskovskogo Universiteta.

Chodakiewicz, M. J. (2012). Intermarium: The land between the Black and Baltic Seas. New Brunswick \& London: Transaction Publishers.

Davies, C. (1982). 'Ethnic jokes, moral values and social boundaries'. The British Journal of Sociology 33 (3), pp. 384-403.

Davies, C. (1987). 'Language, identity, and ethnic jokes about stupidity'. International Journal of the Sociology of Language 65, pp. 39-52.

Davies, C. (1990). Ethnic Humor Around the World: A Comparative Analysis. Bloomington: Indiana University Press.

Davies, C. (1991). 'Fooltowns: Traditional and modern, local, regional and ethnic jokes about stupidity', in Bennett, G. (ed.), Spoken in Jest. The Folklore Society Mistleose Series 21. Sheffield: Sheffield Academic Press, pp. 215-235.

Davies, C. (1998). Jokes and their Relation to the Society. Humour Research Series. Berlin, New York: Walter de Gruyter.

Davies, C. (1999). 'Change and continuity in one of Europe's oldest comic ethnic scripts'. Humor: International Journal of Humor Research 12 (1), pp. 1-31.

Davies, C. (2002). The Mirth of Nations. New Brunswick: Transaction Publishers.

Davies, C. (2003). 'Jokes that follow mass-mediated disasters in a global electronic age, in Narvaez, P. (ed.), Of Corpse: Death and Humor in Folklore and Popular Culture. Logan: Utah State University Press, pp. 15-34.

Davies, C. (2011). Jokes and Targets. Bloomington: Indiana University Press.

Davies, C. (2016). 'Constructing and testing hypotheses on the basis of international comparisons: the case of the Stupidity Joke'. Lecture delivered at the 16th International Summer School and Symposium on Humour and Laughter: Theory, Research and Applications, Brasov, Romania, July 4-9.

Eisen, Matthias J. (1909/2003). Eesti Rahvanali. ['Estonian Folk Joke']. Retrieved 20 October 2017 from http://www.folklore.ee/rl/pubte/ee/vanad/eisen/ernali/sisu.html.

Famichova, N. (2011). 'Mounyja srodki vyrazhennya kamichnaga u belaruskim gumarystychnym fal'klory' ['Linguistic means of comic representation in Belarusian humorous folklore], Belaruskaya Lingvistika 67 (1), pp. 140-145.

Fine, G. \& Soucey, M. (2005). 'Joking cultures: Humor themes as social regulation in group life', Humor: International Journal of Humor Research 18 (1), pp. 1-22.

Järviö-Nieminen, I. (1959). 'Suomalaiset sanomukset' ['Finnish Wellerisms']. Suomalaisen Kirjallisuuden Seuran toimituksia 259. Helsinki: Suomalaisen Kirjallisuuden Seura.

Karpovich, O. \& Gil', V. (2008). 'Vse v Avciuki!' ['Let everybody go to Auciuki!']. August 2. Sovetskaya Belorussiya- Belarus Segodnya. Retrieved 19 October 2017 from https://www.sb.by/articles/vse-v-avtyuki.html?delete_comment_id=

Krikmann, A. (2007). 'Soviet and Baltic nationalities as ethnic targets in contemporary Russian jokes'. A paper presented to the ISHS 19th Annual Conference hosted by Salve Regina University, Newport, Rhode Island, July 1; Retrieved 20 October 2017 from http://www.folklore.ee/ kriku/HUUMOR/Nlj_pribalts.pdf

Krikmann, A. (2008). “"ATU” Jokes: Old and Abandoned'. A paper presented to the ISHS 20th annual conference hosted by the University of Alcala, Alcala de Henares, Madrid, 


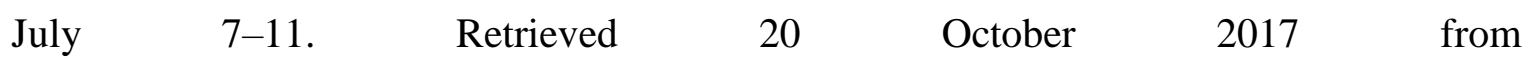
http://haldjas.folklore.ee/ kriku/HUUMOR/KRIKMANN_ATU_ready.pdf.

Kuipers G. (2002). 'Media culture and Internet disaster jokes: Bin Laden and the attack on the World Trade Center', European Journal of Cultural Studies 5(4), pp. 450-470.

Kuipers G. (2006). 'The social construction of digital danger: debating, defusing and inflating the moral dangers of online humor and pornography in the Netherlands and the United States', New Media \& Society 8(3), pp. 379-400.

Kuipers G. \& van der Ent, B. (2016). 'The seriousness of ethnic jokes: Ethnic humor and social change in the Netherlands, 1995-2012', Humor: : International Journal of Humor Research 29 (4), pp. 605-633.

Laineste, L. \& Voolaid, P. (2016). 'We believe! Online representations of the Olympic winner as a mythic hero', Folklore: Electronic Journal of Folklore 54, pp. 9-38.

Laineste, L. (2005). 'Targets of Estonian ethnic jokes within the theory of ethnic humour (C. Davies)', Folklore: Electronic Journal of Folklore 29, pp. 7-24.

Laineste, L. (2009). 'Politics of joking: Ethnic jokes and their targets in Estonia (1890s2007)', Folklore: Electronic Journal of Folklore 40, pp. 117-146.

Mel'nichenko, M. (2014). Sovetskij Anekdot (Ukazatel' Syuzhetov) ['The Soviet joke: plots classification']. Moscow: Novoe literaturnoe obozrenie.

Roosa, A. (2016). Hiidlase vähene naljaraamand ['Little Hiiu Joke Book']. Kärdla: MTÜ Hiiu Öko.

Schutz C. (1989). 'The sociability of ethnic jokes', Humor: International Journal of Humor Research 2(2), pp. 165-177.

Serzhputovsky, A. (1911). Skazki i rasskazy belorusov-poleshukov: (materialy r izucheniyu tvorchestva belorusov $i$ ih govora) ['Tales and stories of Belarusian Poleshuks: (Data for studying Belarusians' art and sheech)']. Saint Petersburg: Otdelenie russkogo yazyka i slovesnosti Imperatorskoj Akademii nauk.

Shein, P. (1893). Materialy dlya izucheniya byta i yazyka russkogo naseleniya SeveroZapadnogo kraya ['Materials for the Studies of the Ways of Life and Language of the North-Western Region Russian population']. Vol. 2. Saint Petersburg: Tipogragija Imperatorskoj Akademii nauk.

Shifman, L. (2007). 'Humor in the age of digital reproduction: Continuity and change in internet-based comic texts', International Journal of Communication 1(1), pp. 187-209.

Tuisk, A. (2010). 'Kolme rahva anekdoodid lastepärimuses: viisteist aastat hiljem' ['Three nation jokes in children's lore: fifteen years later'], in Kalmre, E. (ed.). Tulnukad ja internetilapsed. Uurimusi laste- ja noortepärimusest ['UFOs and Internet children. Studies on children's and teen's lore']. Tartu: EKM Teaduskirjastus. (Tänapäeva folkloorist; VIII), pp. 163-186

Wickberg, D. (1998) The Senses of Humour: Self and Laughter in Modern America. Ithaca, NY: Cornell University Press.

Zhvaleuskaya, A. (2013). 'Specyfika vykarystannya etnichnyh zhartau u etnalagichnym dasledavanni' ['Reflections on the ethnological study of ethnic jokes'], Pytanni mastactvaznaustva, etnalogii $i$ fal'klora [Journal of art history, ethnology, and folkloristics]15, pp. 281-285.

Zhvaleuskaya, A. (2015). 'Etnichnyja zharty yak nemateryjal'naya kul'turnaya spadchyna belarusau: suchasnyja transfarmacyi'. ['Ethnic jokes as Belarusians' intangible cultural heritage: modern transformations']. Evropa-2014: gumanitarnoe znanie mezhdu proshlym i budushchim [Europe 2014: Humanities Between Past and Future]. Vilnius: EGU, pp. 251-260. 
Zinovsky, V. I. et al. [eds.] (2011). Nacional'nyj sostav naseleniya Respubliki Belarus': statisticheskij sbornik ['Ethnic composition of the population of the Republic of Belarus: Statistical book']. Minsk: Nacional'nyj statisticheskij komitet Respubliki Belarus'. 